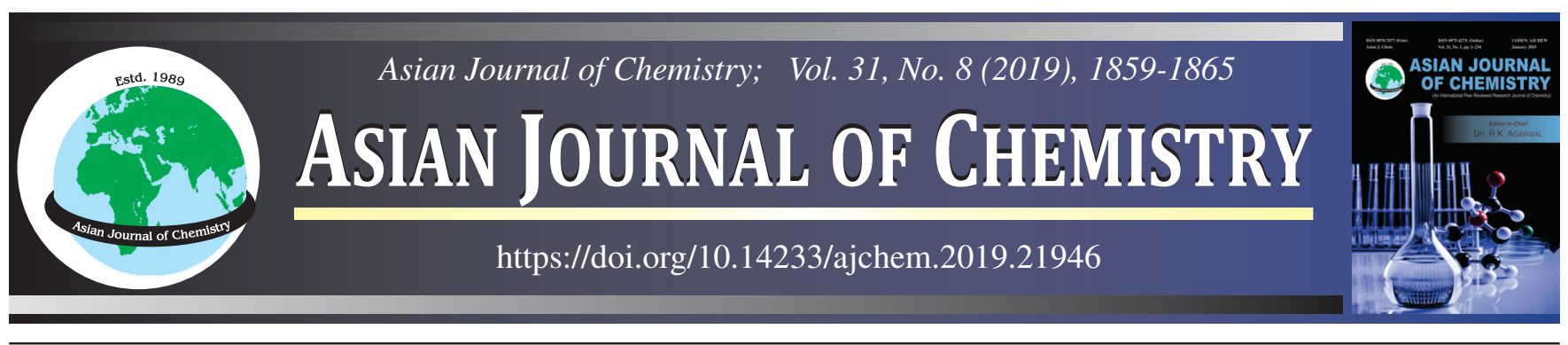

\title{
Optimization of Extraction Parameters for Antioxidant and Total Phenolic Content of Ficus carica L. Latex from White Genoa Cultivar
}

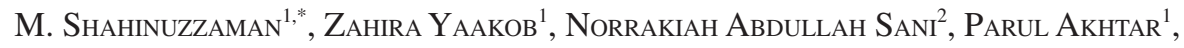 Md. Zahidul Islam ${ }^{3}$, Mst. Afsana Mimi ${ }^{4}$ and Shamsul Akmal Shamsudin ${ }^{5}$}

\begin{abstract}
${ }^{1}$ Department of Chemical and Process Engineering, Faculty of Engineering and Built Environment, Universiti Kebangsaan Malaysia, Bangi, Selangor 43600, Malaysia

${ }^{2}$ Centre for Biotechnology and Functional Food, Faculty of Science and Technology, Universiti Kebangsaan Malaysia, Bangi, Selangor 43600, Malaysia

${ }^{3}$ Department of Chemistry, Faculty of Arts and Science, Sakarya University, 54187 Sakarya, Turkey

${ }^{4}$ Department of Applied Chemistry and Chemical Engineering, Faculty of Engineering and Technology, Islamic University Kushtia, Bangladesh ${ }^{5}$ Saf Fa Fig Garden, Kuala Pilah 72000, Negeri Sembilan, Malaysia
\end{abstract}

*Corresponding author: Fax: +60 389216148; Tel: +60 389216420; E-mail: shahinchmiu@ gmail.com

\begin{abstract}
In this study, the extraction parameters for antioxidant activity and total phenolic content of Ficus carica L. latex from White Genoa cultivar were optimized using response surface methodology (RSM). Effect of temperature, extraction time and solvent concentration for maceration extraction were investigated. The antioxidant activity was determined with DPPH (1,1-diphenyl-2-picrylhydrazyl) assay and expressed as percent of inhibition. Total phenolic content (TPC) was determined with Folin-Ciocalteu assay and expressed as $\mu \mathrm{g}$ GAE/ $\mathrm{mL}$. The optimum points that maximize the DPPH inhibition are $32{ }^{\circ} \mathrm{C}$ temperature, 31.50 min extraction time and $65 \%$ ethanol. The optimum points for TPC are $32{ }^{\circ} \mathrm{C}$ temperature, $37.50 \mathrm{~min}$ extraction time and $70 \%$ ethanol. The predicted DPPH inhibition and TPC at these predicted points are $67.08 \%$ and $313.811 \mu \mathrm{g}$ GAE/mL respectively. In this model, the F value (26.03 and 20.96), R-Squared value (0.9591 and 0.9497$)$ and signal to noise ratio (13.431 and 12.799) are reasonable to fit the model.
\end{abstract}

Keywords: Ficus carica, Latex, Antioxidant, Total phenol, RSM, Optimization.

\section{INTRODUCTION}

At present, various undesirable disorders and negative health effects have been identified as side-effects of using conventional synthetic antioxidants. Due to this, the interest in studies of natural additives as potential antioxidants is increasing. Ficus carica L. commonly referred as "fig" is an important medicinal plant which is one of the first plants that were cultivated by humans. The fig is an important harvest worldwide for its dry and fresh consumption. Figs are the good source of antioxidants and phenolic compounds, such as pro-anthocyanidins. Tea and red wine are two good sources of phenolic compounds, but fig contain higher content of phenols than tea and red wine [1]. The leaves, fruit and root of it are used as the traditional medicine to treat various ailments. They are used as respiratory (coughs, sore throats and bronchial problems), gastrointestinal (colic, indigestion and diarrhea), cardiovascular disorders and as anti-inflammatory and antispasmodic remedy [2].

The latex of fig shows various ethno-medicinal properties like chitinolytic activity, antifungal activity, milk clotting activity [3], cytotoxic and antiviral activities [4,5], antibacterial activity [6], antioxidant capacity, anthelmintic activity [7]. According to Camero et al. [4], the Ficus carica L. latex shows antiviral properties against some human viruses. Traditionally, the fig latex (fruit) is used as the medicine to treat some of the skin infections such as warts [5]. The latex from Tunisian common Jrani Capri fig showed antibacterial activity against some of the Gram-positive and Gram-negative bacteria [6].

There are various extraction methods which are now used to extract of bioactive compounds from various plant sources such as maceration extraction [8], microwave-assisted extraction

This is an open access journal, and articles are distributed under the terms of the Attribution 4.0 International (CC BY 4.0) License. This license lets others distribute, remix, tweak, and build upon your work, even commercially, as long as they credit the author for the original creation. You must give appropriate credit, provide a link to the license, and indicate if changes were made. 
[9-11], supercritical fluid extraction [12,13] and ultrasoundassisted extraction (UAE) $[14,15]$. But most of these methods are time consuming or require relatively more solvents and are not economically viable because of the higher cost. However, as an environment-friendly technique maceration extraction process is better among the other methods. This extraction method also beneficial for good reproducibility, relatively less solvent, less time, low temperature and low energy input as well as easy scale up for the applications of industries. Also, in the maceration process, it can be absorbed the higher amount of solvent to swells the dried plants [16]. As a result, pores of cell walls are enlarged which can permit greater diffusivity on the cell walls $[17,18]$.

The optimization process can be used to improve the performance of any system or process or product to obtain the maximum benefit from it $[19,20]$. It provides an elegant blend of theory and applications. The optimization process could be performed by either experimental method or statistical method [21]. To study the observation technique in one-factor-at-atime, all the factors are kept constant and only one factor is changing [22]. Response surface methodology (RSM) is an important mathematical and statistical technique to evaluate the effect of response variables and the interaction between the multiple factors with one or more response variables [23]. Numerous RSM design have been widely used such as BoxBehnken design (BBD), central composite design (CCD), Doehlert design and three-level full factorial design (TFFD). Among them the central composite design is the powerful design that is time saving and more suitable than the other designs. It has been used to develop, improve and optimize the parameters for extract a wide range of antioxidants and other metabolites from natural sources $[24,25]$. To the best of our knowledge, there has no enough data of the antioxidant activity of White Genoa fig cultivar and the optimization of this cultivar with RSM. Hence, the aim of this study is to optimize the antioxidant activity and total phenolic content of White Genoa fig latex by using RSM in maceration extraction process.

\section{EXPERIMENTAL}

Potassium persulfate, anhydrous sodium carbonate, monohydrate gallic acid and ethanol were from Friendemann Schmidt, Australia; Folin-Ciocalteu reagent was from Merck Millipore (Germany); 1,1-diphenyl-2-picrylhydrazyl (DPPH), 6-hydroxy2,5,7,8-tetramethylchroman-2-carboxylic acid (Trolox) were from Sigma-Aldrich (USA). Milli-Q water was used for the preparation of reactant solutions, standard materials and extraction.

The latex sample from White Genoa cultivar of Ficus carica were collected from Saf Fa Fig Garden in Living lab energy and future crops laboratories at Kuala Pilah, Negeri Sembilan, Malaysia, under the Faculty of chemical and process engineering, Universiti Kebangsaan Malaysia. The White Genoa cultivar of F. carica were identified and collected from forest research institute of Liaoning, China. Latex was collected manually by incising the stem of the matured green leaves. The latex was obtained drop-by-drop in glass vial without squeezing. Then the latex was homogenized, weighted, separated by aliquots and used for the analysis.
Sample preparation and extraction: For the maceration extraction, same amount of fig latex ( $1 \mathrm{~g}$ ) from White Genoa cultivar was kept in a capped long test-tube and added required volume of solvent. After that the mixture was used for extraction. An incubator shaker (Model SI 50) at $240 \mathrm{rpm}$ was used to extract the samples from fig latex. After shaking, the sample was centrifuged at $4000 \mathrm{rpm}$ for $10 \mathrm{~min}$ by using a laboratories centrifuge machine. Then the supernatant liquid was filtered and collect into the glass sample vial and directly used for the determination of antioxidant activity, total phenolic content and other analysis [8,26].

Determination of antioxidant capacity with DPPH free radical scavenging assay: Antiradical activity were determined spectrophotometrically by monitoring the disappearance of $\mathrm{DPPH}^{\bullet}$ at $520 \mathrm{~nm}$, according to a described procedure with some modifications [26]. The reaction mixtures in the sample consisted of $100 \mu \mathrm{L}$ of supernatant and $2.9 \mathrm{~mL}$ of 0.05 $\mathrm{mM}$ DPPH dissolved in methanol. The samples were incubated for $30 \mathrm{~min}$ at room temperature. Three experiments were performed for every sample.

Determination of total phenolic content: The total phenolic content (TPC) of Ficus carica were determined by the Folin-Ciocalteu assay with a little modification [27] using a spectrophotometer (Shanghai, China). Firstly, $100 \mu \mathrm{L}$ of the standard gallic acid or latex extract were mixed with $3.25 \mathrm{~mL}$ of 12 times pre-diluted of Folin-Ciocalteu reagent. The samples and standards were properly mixed and allowed to stand for 7 min; then added $750 \mu \mathrm{L}$ of $20 \% \mathrm{Na}_{2} \mathrm{CO}_{3}$ in the main solution containing test-tube and allowed to $2 \mathrm{~h}$ for incubation at room temperature and dark conditions. Finally, the absorbance was recorded at $760 \mathrm{~nm}$ based on colorimetric redox reaction from a standard curve $\left(\mathrm{y}=0.0033 \mathrm{x}+0.0473, \mathrm{R}^{2}=0.9951\right)$ and using standard gallic acid solution of 31.25 to $500 \mu \mathrm{g} / \mathrm{mL}$. The results were presented as $\mu \mathrm{g}$ gallic acid equivalent (GAE)/ $\mathrm{mL}$. Each standard and extract were measured in three times.

Experimental design for optimization: Response surface methodology (RSM) and a central composite design (CCD) were used to study the effect of extraction parameters for obtaining the highest antioxidant activity and phenolic content from the latex of White Genoa cultivar of $F$. carica with maceration extraction. For the extraction process, three independent variables viz. temperature $\left({ }^{\circ} \mathrm{C}\right)$, extraction time ( $\left.\mathrm{min}\right)$ and solvent concentration (\%) were used on the responses of two dependent variables viz. antioxidant activity (DPPH scavenging assay) and total phenolic content (TPC). The design of extraction consisting of 20 experimental runs with the six replication experiments at design centre points $\left(35^{\circ} \mathrm{C}\right.$ temperature, $30 \mathrm{~min}$ extraction time and $75 \%$ solvent concentration). The fit quality of polynomial model was expressed by the coefficient of determination $\mathrm{R}^{2}$ and is statistical significance that was checked by the F-test.

Temperature $\left({ }^{\circ} \mathrm{C}\right)$, extraction time $(\mathrm{min})$ and solvent concentration (\%) was considered to study the extraction conditions based on the previous study and primary screening of this research. For the maceration extraction of fig latex; 20$50{ }^{\circ} \mathrm{C}$ temperature, $15-45$ min extraction time and 50-100\% solvent concentration were used. The experimental design and the outcomes of the experiments are shown in Table-1. 


\begin{tabular}{|c|c|c|c|c|c|}
\hline \multicolumn{6}{|c|}{$\begin{array}{c}\text { TABLE-1 } \\
\text { DESIGN OF EXPERIMENT (DOE) OF CENTRAL } \\
\text { COMPOSITE DESIGN (CCD) USED IN RSM ANALYSIS } \\
\text { TOGETHER WITH RESPONSE FOR DPPH AND } \\
\text { TPC WITH MACERATION EXTRACTION }\end{array}$} \\
\hline Run & $\begin{array}{l}\text { Temp. } \\
\left({ }^{\circ} \mathrm{C}\right)\end{array}$ & $\begin{array}{l}\text { Time } \\
\text { (min) }\end{array}$ & $\begin{array}{l}\text { Solvent } \\
(\%)\end{array}$ & $\begin{array}{c}\text { Antioxidant } \\
\text { activity (DPPH } \\
\text { inhibition \%) }\end{array}$ & $\begin{array}{c}\text { TPC } \\
(\mu \mathrm{g} \mathrm{GAE} / \mathrm{mL})\end{array}$ \\
\hline 1 & 20.00 & 15.00 & 100.00 & 37.30 & 284.45 \\
\hline 2 & 35.00 & 30.00 & 50.00 & 62.12 & 309.23 \\
\hline 3 & 50.00 & 30.00 & 75.00 & 60.77 & 299.60 \\
\hline 4 & 35.00 & 30.00 & 100.00 & 53.62 & 293.51 \\
\hline 5 & 20.00 & 30.00 & 75.00 & 59.77 & 308.67 \\
\hline 6 & 35.00 & 45.00 & 75.00 & 48.50 & 307.56 \\
\hline 7 & 20.00 & 45.00 & 100.00 & 38.18 & 288.27 \\
\hline 8 & 20.00 & 15.00 & 50.00 & 43.35 & 293.54 \\
\hline 9 & 35.00 & 30.00 & 75.00 & 69.49 & 312.94 \\
\hline 10 & 50.00 & 45.00 & 50.00 & 47.08 & 298.33 \\
\hline 11 & 20.00 & 45.00 & 50.00 & 57.81 & 304.93 \\
\hline 12 & 35.00 & 30.00 & 75.00 & 68.34 & 313.55 \\
\hline 13 & 50.00 & 15.00 & 50.00 & 43.57 & 276.46 \\
\hline 14 & 50.00 & 15.00 & 100.00 & 37.77 & 283.04 \\
\hline 15 & 50.00 & 45.00 & 100.00 & 35.00 & 286.00 \\
\hline 16 & 35.00 & 30.00 & 75.00 & 64.27 & 314.65 \\
\hline 17 & 35.00 & 30.00 & 75.00 & 69.49 & 304.87 \\
\hline 18 & 35.00 & 30.00 & 75.00 & 62.34 & 313.08 \\
\hline 19 & 35.00 & 15.00 & 75.00 & 47.73 & 305.00 \\
\hline 20 & 35.00 & 30.00 & 75.00 & 68.07 & 312.33 \\
\hline
\end{tabular}

\section{RESULTS AND DISCUSSION}

Fitting the RSM models: According to the analysis of ANOVA and the fit summary, the quadratic (antioxidant and TPC) polynomial models were found to be suggested and significant based on their probability, Prob $>\mathrm{F}$ value $<0.050$ (Table-3). On the other hand, the higher $\mathrm{R}^{2}$ values ( 0.9591 for DPPH, 0.9497 for TPC) and the lower standard deviation (3.33 for DPPH and 3.63 for TPC) in quadratic model of the model summary statistics (Table-2) compared to the linear model was used for the execution of this research. The higher $\mathrm{R}^{2}$ value indicates that there is a good agreement between the observed and predicted values of antioxidant activity and total phenolic content.

In case of antioxidant activity, the model F-value is 26.03 (Table-3). This value indicates that the model is significant. The model terms can be significant for the "Prob $>$ F" value less than 0.0500. In this case the solvent concentration (C), second order term of extraction time $\left(\mathrm{B}^{2}\right)$ and second order term of solvent concentration $\left(\mathrm{C}^{2}\right)$ are significant model terms. This means the antioxidant activity is significantly influenced by the solvent concentration, second order term of extraction of time and second order term of solvent concentration. The "Lack of Fit F-value" is 1.49 (Table-3) which indicates the "Lack of Fit" is not significant and it is because of the pure error. There is a $33.54 \%$ chance that a "Lack of Fit F-value" this large could occur because of the noise. The current model

TABLE-2

MODEL SUMMARY STATISTICS FOR DPPH AND TPC

\begin{tabular}{cccccc|ccccc}
\hline \multirow{2}{*}{ Source } & \multicolumn{4}{c|}{ Antioxidant activity } & \multicolumn{4}{c}{ Total phenolic content } \\
\cline { 2 - 10 } & $\mathrm{SD}$ & $\mathrm{R}^{2}$ & $\mathrm{R}_{\text {Adj }}^{2}$ & $\mathrm{R}_{\text {Pre }}^{2}$ & Comment & SD & $\mathrm{R}^{2}$ & $\mathrm{R}_{\text {Adj }}^{2}$ & $\mathrm{R}_{\text {Pre }}$ Comment $^{\text {Com }}$ \\
\hline Linear & 12.24 & 0.1160 & -0.0498 & -0.5104 & - & 11.44 & 0.1985 & 0.0483 & -0.4479 & - \\
2FI & 13.34 & 0.1468 & -0.2469 & -4.5105 & - & 2.21 & 0.2573 & -0.0855 & -4.3743 & - \\
Quadratic & 3.33 & 0.9591 & 0.9222 & 0.8109 & Suggested & 3.63 & 0.9497 & 0.9044 & 0.7073 & Suggested \\
Cubic & 3.88 & 0.9667 & 0.8944 & -19.817 & Significant & 3.26 & 0.9756 & 0.9228 & 0.3678 & Significant \\
\hline
\end{tabular}

TABLE-3

ANALYSIS OF VARIANCE TABLE (ANOVA) FOR RESPONSE SURFACE QUADRATIC MODEL FOR ANTIOXIDANT ACTIVITY (DPPH) AND TOTAL PHENOLIC CONTENT (TPC)

\begin{tabular}{|c|c|c|c|c|c|c|c|c|c|c|c|c|c|}
\hline \multicolumn{7}{|c|}{ DPPH } & \multicolumn{7}{|c|}{ TPC } \\
\hline Source & $\begin{array}{r}\text { Sum of } \\
\text { Squares }\end{array}$ & $\mathrm{DF}$ & $\begin{array}{c}\text { Mean } \\
\text { Square }\end{array}$ & $\begin{array}{c}\mathrm{F} \\
\text { Value }\end{array}$ & $\begin{array}{c}\text { Prob }> \\
F\end{array}$ & Status & Source & $\begin{array}{l}\text { Sum of } \\
\text { Squares }\end{array}$ & $\mathrm{DF}$ & $\begin{array}{c}\text { Mean } \\
\text { Square }\end{array}$ & $\begin{array}{l}\mathrm{F} \\
\text { Value }\end{array}$ & $\begin{array}{c}\text { Prob }> \\
F\end{array}$ & Status \\
\hline Model & 2599.03 & 9 & 288.78 & 26.03 & $<0.0001$ & Significant & Model & 2480.26 & 9 & 275.58 & 20.96 & $<0.0001$ & Significant \\
\hline A & 14.93 & 1 & 14.93 & 1.35 & 0.2730 & & A & 115.12 & 1 & 115.12 & 8.76 & 0.0143 & \\
\hline B & 28.39 & 1 & 28.39 & 2.56 & 0.1408 & & B & 203.40 & 1 & 203.40 & 15.47 & 0.0028 & \\
\hline $\mathrm{C}$ & 271.02 & 1 & 271.02 & 24.43 & 0.0006 & & $\mathrm{C}$ & 199.99 & 1 & 199.99 & 15.21 & 0.0030 & \\
\hline $\mathrm{A}^{2}$ & 24.78 & 1 & 24.78 & 2.23 & 0.1659 & & $\mathrm{~A}^{2}$ & 140.43 & 1 & 140.43 & 10.68 & 0.0085 & \\
\hline $\mathrm{B}^{2}$ & 631.76 & 1 & 631.76 & 56.93 & $<0.0001$ & & $\mathrm{~B}^{2}$ & 68.78 & 1 & 68.78 & 5.23 & 0.0452 & \\
\hline $\mathrm{C}^{2}$ & 80.24 & 1 & 80.24 & 7.23 & 0.0227 & & $\mathrm{C}^{2}$ & 270.12 & 1 & 270.12 & 20.55 & 0.0011 & \\
\hline $\mathrm{AB}$ & 26.64 & 1 & 26.64 & 2.40 & 0.1523 & & $\mathrm{AB}$ & 18.36 & 1 & 18.36 & 1.40 & 0.2646 & \\
\hline $\mathrm{AC}$ & 7.60 & 1 & 7.60 & 0.69 & 0.4271 & & $\mathrm{AC}$ & 63.28 & 1 & 63.28 & 4.81 & 0.0530 & \\
\hline $\mathrm{BC}$ & 49.30 & 1 & 49.30 & 4.44 & 0.0613 & & $\mathrm{BC}$ & 71.88 & 1 & 71.88 & 5.47 & 0.0415 & \\
\hline Residual & 110.96 & 10 & 11.10 & & & & Residual & 131.45 & 10 & 13.15 & & & \\
\hline $\begin{array}{c}\text { Lack of } \\
\text { Fit }\end{array}$ & 66.45 & 5 & 13.29 & 1.49 & 0.3354 & $\begin{array}{c}\text { Not } \\
\text { Significant }\end{array}$ & $\begin{array}{c}\text { Lack of } \\
\text { Fit }\end{array}$ & 69.09 & 5 & 13.82 & 1.11 & 0.4567 & $\begin{array}{c}\text { Not } \\
\text { Significant }\end{array}$ \\
\hline Pure & 44.51 & 5 & 8.90 & & & & Pure & 62.36 & 5 & 12.47 & & & \\
\hline Error & & 19 & & & & & Error & & 19 & & & & \\
\hline $\begin{array}{l}\text { Core } \\
\text { total }\end{array}$ & & & & & & & $\begin{array}{l}\text { Core } \\
\text { total }\end{array}$ & & & & & & \\
\hline
\end{tabular}

$\mathrm{A}=$ Temperature $\left({ }^{\circ} \mathrm{C}\right) ; \mathrm{B}=$ Time $(\mathrm{min}) ; \mathrm{C}=$ Solvent concentration $(\%)$ 
is fit for the non-significant lack of fit value which is a good agreement. The difference between the "Pred R-Squared" value $(0.8109)$ and the "Adj R-Squared" value (0.9222) is less then 0.20 and this is the reasonable agreement of this model. In this case the ratio of signal and nois (Adeq precision) is 13.431 which is more than 4.0 and indicate the model is fit.

In case of the total phenolic content, the Model F-value of 20.96 (Table-3). In this value the model is significant. There is only a $0.01 \%$ chance that a "Model F-Value" this large could occur due to noise. In this case temperature (A), time (B), solvent concentration $(C)$, second term of temperature $\left(\mathrm{A}^{2}\right)$, second term of time $\left(\mathrm{B}^{2}\right)$, second term of solvent concentration $\left(\mathrm{C}^{2}\right)$ and two interaction terms of time and solvent concentration (BC) are significant model terms. This means the total phenolic content is significantly influenced by temperature, time, solvent concentration, second term of temperature, second term of time, second term of solvent concentration and two interaction terms of time and solvent concentration. On the TPC, the "Lack of Fit F-value" is 1.11 which indicates the Lack of Fit is not significant and it is because of the pure error. The difference between the "Pred R-Squared" value (0.7073) and the "Adj RSquared" value (0.9044) (Table-2) is less then 0.20 which indicates the current model is in a reasonable agreement. "Adeq Precision" measures the signal to noise ratio. In this case the ratio of signal and nois (Adeq Precision) is 12.799 which is more than 4.0 and indicate the model is fit to navigate the design space.

The second order polynomial equation correlating the three extraction variables with the responses in terms of coded factors for the extraction process can be expressed as follows:

\section{Maceration extraction:}

$$
\begin{aligned}
& \mathrm{DPPH}=+65.51-1.22 * \mathrm{~A}+1.69 * \mathrm{~B}-5.21 * \mathrm{C}- \\
& 3.00 * \mathrm{~A}^{2}-15.16 * \mathrm{~B}^{2}-5.40 * \mathrm{C}^{2}-1.83 * \mathrm{~A} * \mathrm{~B}+ \\
& 0.98 * \mathrm{~A} * \mathrm{C}-2.48 * \mathrm{~B} * \mathrm{C} \\
& \mathrm{TPC}=+311.65-3.39 * \mathrm{~A}+4.51 * \mathrm{~B}-4.47 * \mathrm{C}- \\
& 7.15 * \mathrm{~A}^{2}-5.00 * \mathrm{~B}^{2}-9.91 * \mathrm{C}^{2}+1.52 * \mathrm{~A} * \mathrm{~B}+ \\
& 2.81 * \mathrm{~A} * \mathrm{C}-3.00 * \mathrm{~B} * \mathrm{C}
\end{aligned}
$$

where $\mathrm{A}, \mathrm{B}$ and $\mathrm{C}$ represents temperature, extraction time and solvent concentration respectively.

Fig. 1 shows the Predicted $v s$. Actual value for antioxidant activity (DPPH) and total phenolic content (TPC) respectively.

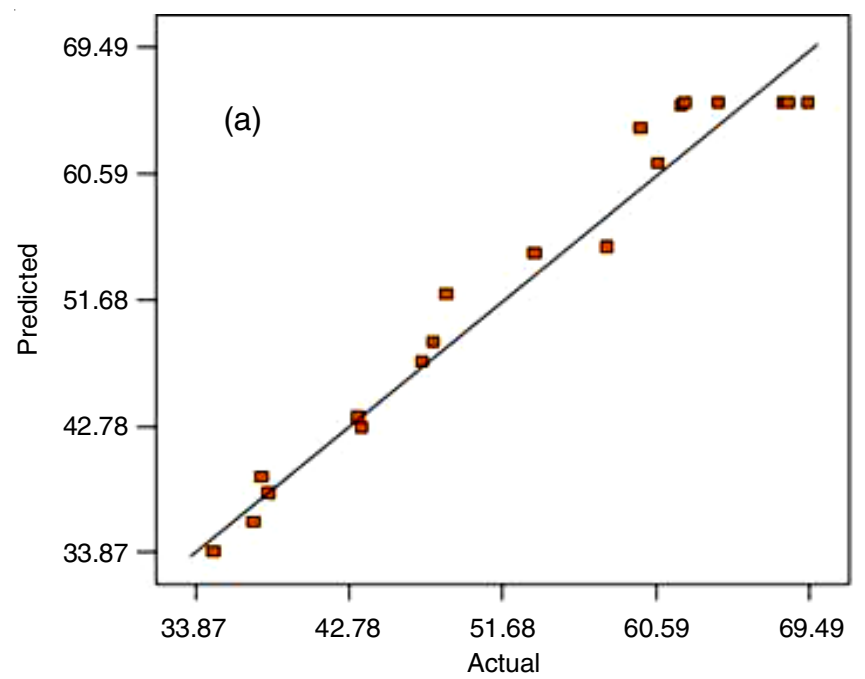

Effect of solvent type and solvent to latex ratio: It is very important to select the proper solvent and solvent to sample ratio for extraction of antioxidant and total phenolic compounds. So, before starting the extraction process for optimization, the solvent type and solvent to sample ratio were investigated. Basically, two types of solvent viz. methanol and ethanol are used for the extraction of antioxidant and total phenolic compounds from plant materials. The antioxidant activity and total phenolic content of fig latex is solvent dependent. The solvent combined with water showed better result instead of pure solvent to extract antioxidant and polyphenols of plant extract [28,29]. In this study the effect of activity with different solvents were performed for DPPH and TPC with methanol, ethanol, $75 \%$ ethanol, ethyl acetate and $n$-hexane. The latex of fig showed highest activity with $100 \%$ methanol (DPPH-66.67 \%, TPC-354.32 mg GAE/ $\mathrm{mL}$ ) followed by $75 \%$ ethanol (DPPH-63.76 \%, TPC-298.15 $\mathrm{mg} \mathrm{GAE} / \mathrm{mL}$ ) and 100 ethanol (DPPH-52.72 \%, TPC-274.62 $\mathrm{mg} \mathrm{GAE} / \mathrm{mL}$ ). But methanol is more toxic [30-33]. So, ethanol was used as the best solvent in this study.

The effect of latex to solvent ratio on the antioxidant activity with DPPH assay and total phenolic content was also studied with four ratios $(1 / 1,1 / 5,1 / 10$ and $1 / 15 \mathrm{~g} / \mathrm{mL})$ over $30{ }^{\circ} \mathrm{C}$ temperature, 35 min extraction time and $75 \%$ ethanol concentration. The antioxidant activity increased with the increased of solvent up to $5 \mathrm{~mL}(71.48 \%)$ of solvent and again decreased with increased of solvent. But the $5 \mathrm{~mL}(71.48 \%)$ and $10 \mathrm{~mL}(66.21 \%)$ solvent showed near to same activity. The total phenolic content decreased with the increased of solvent up to $15 \mathrm{~mL}(234.03 \mu \mathrm{g} \mathrm{GAE} / \mathrm{mL})$ of solvent. There were significant differences between $1 \mathrm{~mL}(340.5 \mu \mathrm{g}$ GAE/ $\mathrm{mL}), 5 \mathrm{~mL}(299.62 \mu \mathrm{g} \mathrm{GAE} / \mathrm{mL})$ and $10 \mathrm{~mL}(291.68 \mu \mathrm{g} \mathrm{GAE} /$ $\mathrm{mL}$ ) solvent. But the higher latex to solvent ratio increase the diffusion rate which increase the extraction of solids by solvent. It also increases the leaching out rates to coming into contact bioactive compounds with solvents. Therefore, a latex to solvent ratio of $1: 10(\mathrm{~g} / \mathrm{mL})$ was chosen for all the experimental runs of this study to make the higher solvent to latex ratio which could maximize the speed of mass transfer. Also, higher ratios of solvent intend to minimize the amount of latex used and maximize the extraction rate and percent of yield [34,35].

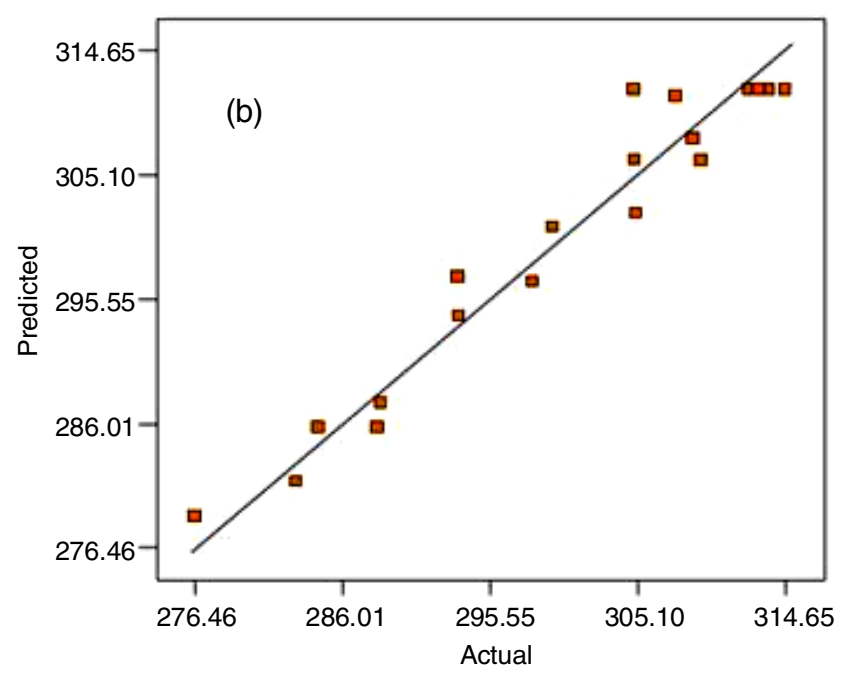

Fig. 1. Predicted value vs. actual value for (a) DPPH and (b) TPC 


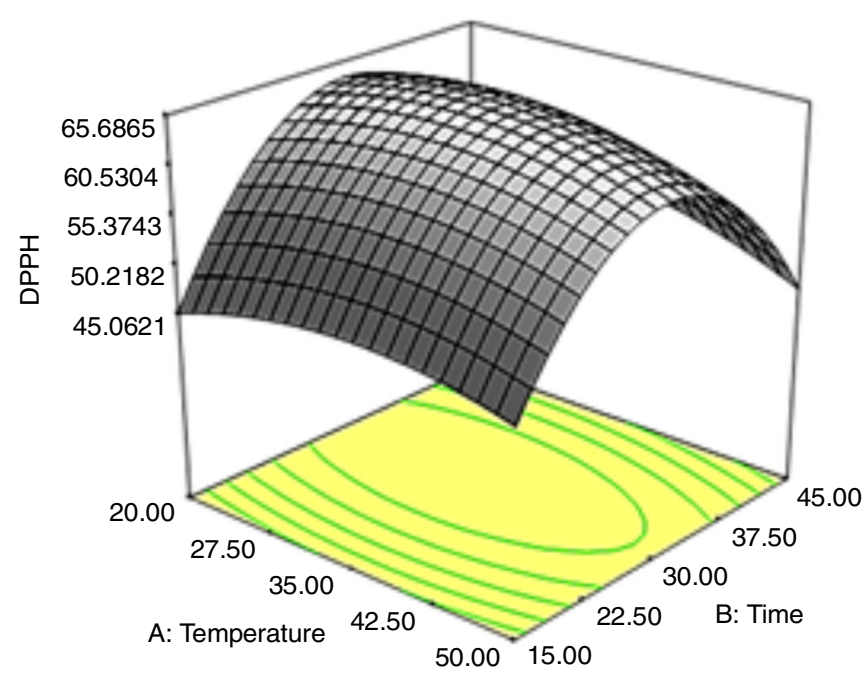

(a)

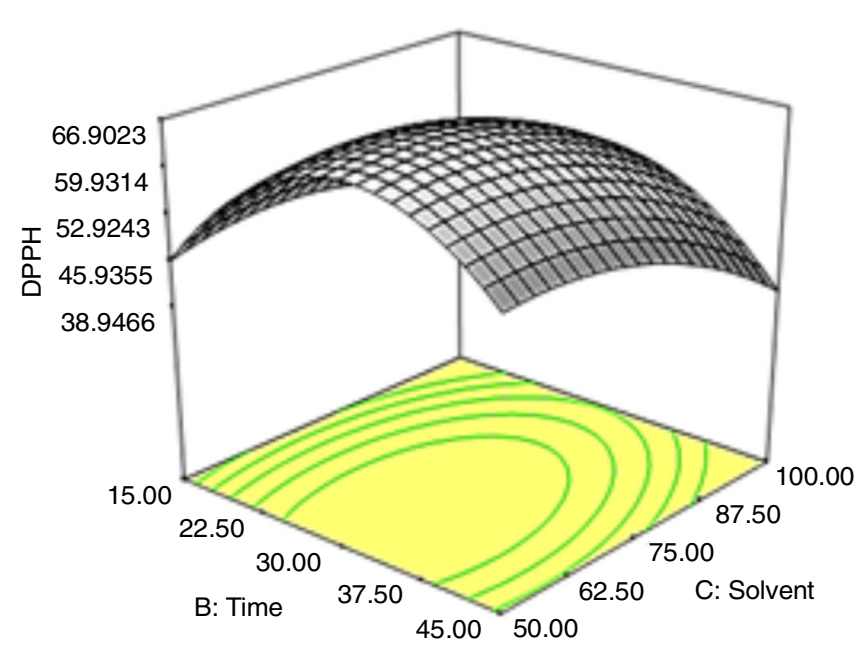

(b)

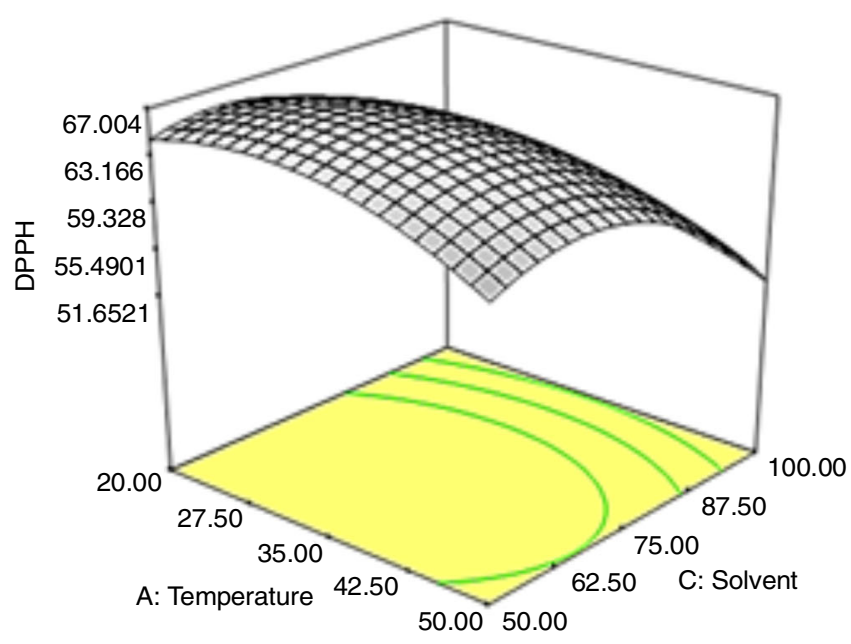

(c)

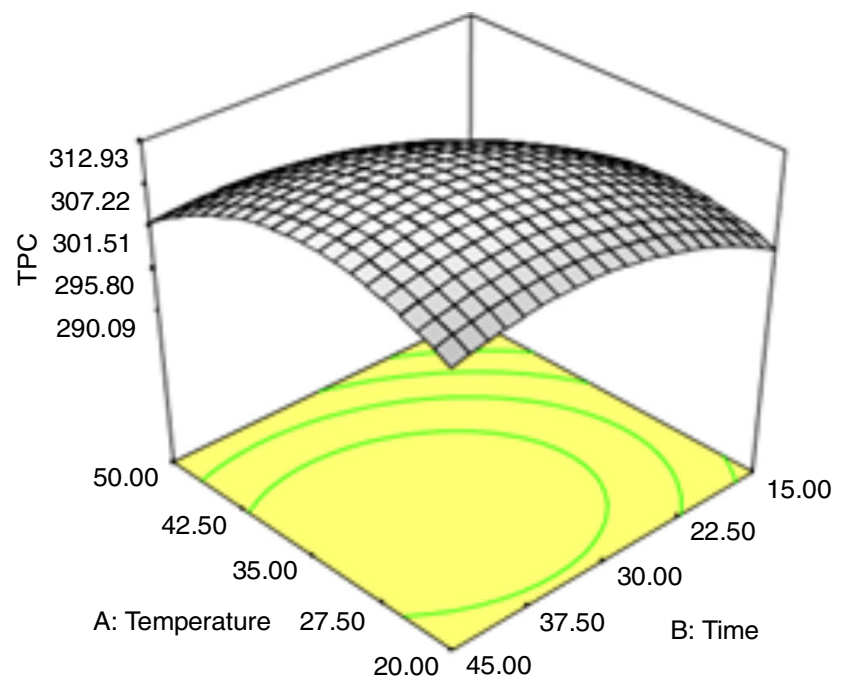

(a)

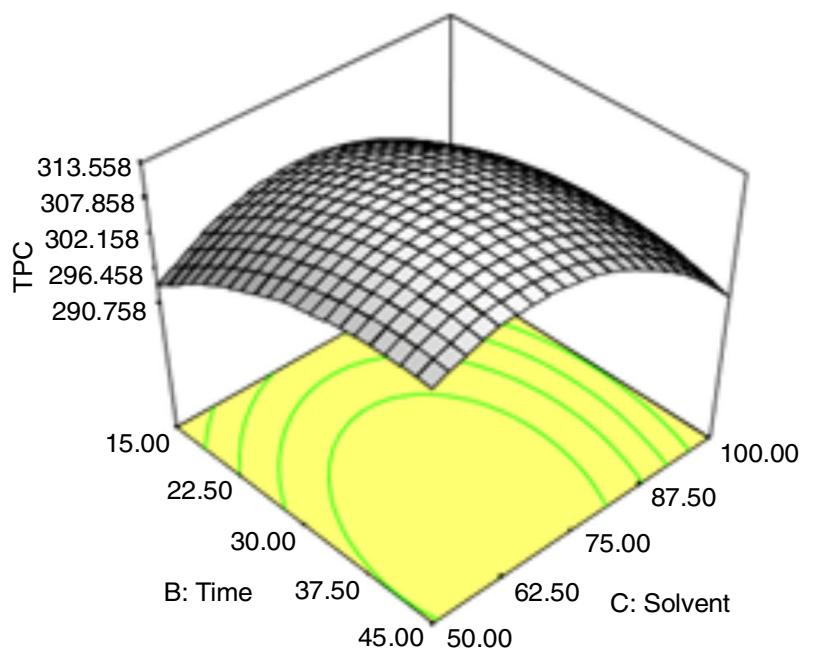

(b)

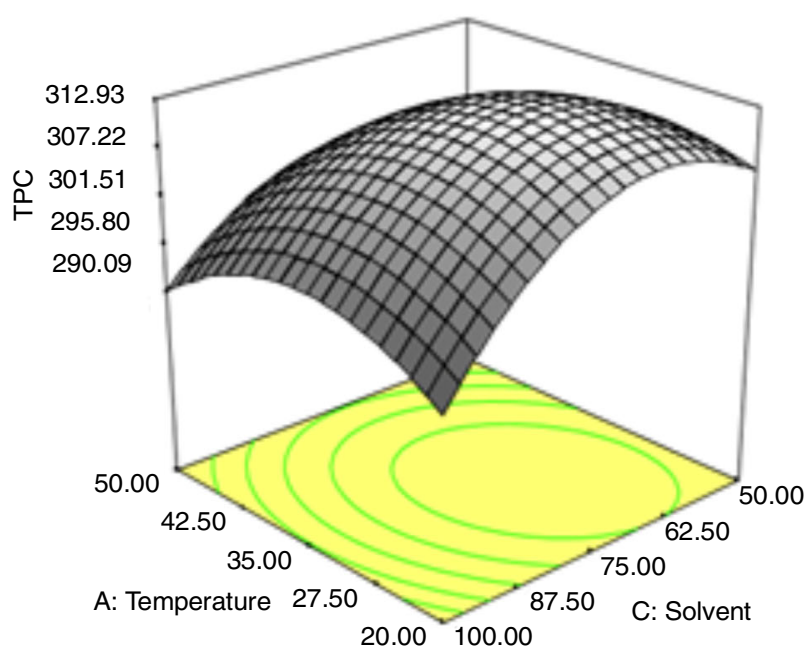

(c)

(A) DPPH

(B) TPC

Fig. 2. Response surface 3D plots showing the effect of different extraction parameters for (A) DPPH scavenging capacity at (a) constant solvent concentration (b) constant temperature and (c) constant time; (B) total phenolic content at (a) constant solvent concentration (b) constant temperature and (c) constant time 
Effect of extraction parameters on antioxidant activity: The effect of extraction parameters for DPPH scavenging activity of fig latex from White Genoa cultivar with maceration extraction is shown in Fig. 2A. In case of maceration extraction, the percent inhibition of DPPH scavenging activity was increased with the increase of extraction temperature, time and solvent concentration from the range of $20-32{ }^{\circ} \mathrm{C}, 15-31.50 \mathrm{~min}$ and $50-65 \%$ respectively. At $32{ }^{\circ} \mathrm{C}$, time of $31.5 \mathrm{~min}$ and $65 \%$ ethanol concentration, it shows highest DPPH activity which is 67.0819 $\%$ and hereafter the DPPH inhibition goes decline by increasing the extraction temperature, time and solvent concentration.

Effect of extraction parameters on total phenolic content: The effect of extraction parameters for total phenolic content of fig latex from White Genoa cultivar with maceration extraction and ultrasonic assisted extraction are shown in Fig. 2B. Fig. 2B(a) shows the effect of extraction temperature and time at constant solvent concentration. There was a slow increase in the total phenolic content with increase in the extraction temperature up to $32{ }^{\circ} \mathrm{C}$ and further increase of temperature beyond $50^{\circ} \mathrm{C}$ showed the decrease of TPC. The effect of extraction time also showed the rapid increase of activity from $15 \mathrm{~min}$ up to 37.50 and $37.50 \mathrm{~min}$ showed the highest TPC value. From the Fig. 2B(b) and 2B(c), the increase of ethanol concentration up to $70 \%$ showed the increase of TPC and a further increase of ethanol concentration beyond $100 \%$ showed the decrease of activity. At the optimum point $\left(32{ }^{\circ} \mathrm{C}, 37.50 \mathrm{~min}\right.$ and $\left.70 \%\right)$ the total phenolic content is $313.811 \mu \mathrm{g} \mathrm{GAE} / \mathrm{mL}$.

Temperature plays an important role in increasing the diffusion co-efficient and solubility to improve the antioxidant activity and total phenolic content of plant extract [23]. The current study showed the favourable results with the previous studies and showed higher or equivalent results for the latex of Calotropis procera [36], Garcinia morella [37], Jatropha neopauciflora P. [38] and Croton lechleri [39], etc.

Optimization and validation of experimental parameters: Numerical optimization was used to optimize the extraction parameters of White Genoa fig latex to get the maximum antioxidant activity and total phenolic content within the given range of extraction variables and to evaluate the response model using point prediction. The points that maximize desirability of DPPH and TPC for maceration extraction are $32{ }^{\circ} \mathrm{C}$ extraction temperature, $31.50 \mathrm{~min}$ and $37.50 \mathrm{~min}$ extraction time and 65 and $70 \%$ solvent concentration. The predicted DPPH inhibition and TPC at these predicted points were $67.0819 \%$ and $313.811 \mu \mathrm{g}$ GAE $/ \mathrm{mL}$ respectively. At the predicted optimum points, the experimental values of DPPH inhibition and TPC were $64.93 \%$ and $311.83 \mu \mathrm{g} \mathrm{GAE} / \mathrm{mL}$ respectively.

\section{Conclusion}

The main objective of this work was to optimize the extraction conditions of White Genoa cultivars of F. carica latex by RSM to maximize the antioxidant activity and phenolic content. Operational parameters such as extraction temperature, extraction time and solvent (ethanol) concentration were investigated for maceration extraction process using central composite design for their effect on antioxidant activity and total phenolic content. The high correlation $\left(\mathrm{R}^{2}=0.9591\right.$ for DPPH, $R^{2}=0.9497$ for TPC) of the model showed that the second-order polynomial model could successfully implies the extraction parameters on the response. The highest antioxidant activity (67.0819\% of DPPH inhibition) and total phenolic content $(313.811 \mu \mathrm{g} \mathrm{GAE} / \mathrm{mL})$ were obtained. The optimum conditions for DPPH are $32{ }^{\circ} \mathrm{C}$ extraction temperature, $31.50 \mathrm{~min}$ extraction time and $65 \%$ solvent concentration. The optimum conditions for TPC are $32^{\circ} \mathrm{C}$ extraction temperature, $37.50 \mathrm{~min}$ extraction time and $70 \%$ solvent concentration. Thus, the generated models can be used to optimize the extraction process for the isolation of antioxidant active phenolic compounds from the White Genoa cultivar of Ficus carica L. latex.

\section{ACKNOWLEDGEMENTS}

This project is financed by Universiti Kebangsaan Malaysia under Grant LIV-2015-04 and DIP-2014-011. The authors would like to thank the university administration for the financial support.

\section{CONFLICT OF INTEREST}

The authors declare that there is no conflict of interests regarding the publication of this article.

\section{REFERENCES}

1. J.A. Vinson, J. Proch and L. Zubik, J. Agric. Food Chem., 47, 4821 (1999); https://doi.org/10.1021/jf990312p.

2. M. Werbach, Harper Perennial, 54, 287 (1993).

3. B. Raskovic, J. Lazic and N. Polovic, J. Sci. Food Agric., 96, 576 (2016); https://doi.org/10.1002/jsfa.7126.

4. M. Camero, M. Marinaro, A. Lovero, G. Elia, C. Buonavoglia, M. Losurdo and M. Tempesta, Nat. Prod. Res., 28, 2031 (2014); https://doi.org/10.1080/14786419.2014.918120.

5. H.L. Aref, B. Gaaliche, A. Fekih, M. Mars, M. Aouni, J.P. Chaumon and K. Said, Nat. Prod. Res., 25, 310 (2011); https://doi.org/10.1080/14786419.2010.528758.

6. H. Lazreg-Aref, M. Mars, A. Fekih, M. Aouni and K. Said, Pharm. Biol., 50, 407 (2012); https://doi.org/10.3109/13880209.2011.608192.

7. A.P. Oliveira, L.R. Silva, F. Ferreres, P. Guedes de Pinho, P. Valentão, B.M. Silva, J.A. Pereira and P.B. Andrade, J. Agric. Food Chem., 58, 3393 (2010); https://doi.org/10.1021/jf9039759.

8. S.A.S. Chatha, A.I. Hussain, J.-U.-R. Bajwa and M. Sagir, J. Food Lipids, 13, 424 (2006); https://doi.org/10.1111/j.1745-4522.2006.00068.x.

9. M. Ranic, M. Nikolic, M. Pavlovic, A. Buntic, S. Siler-Marinkovic and S. Dimitrijevic-Brankovic, J. Clean. Prod., 80, 69 (2014); https://doi.org/10.1016/j.jclepro.2014.05.060.

10. F. Dahmoune, B. Nayak, K. Moussi, H. Remini and K. Madani, Food Chem., 166, 585 (2015); https://doi.org/10.1016/j.foodchem.2014.06.066.

11. M. Bouras, M. Chadni, F.J. Barba, N. Grimi, O. Bals and E. Vorobiev, Ind. Crops Prod., 77, 590 (2015); https://doi.org/10.1016/j.indcrop.2015.09.018.

12. K. Ghafoor, J. Park and Y.-H. Choi, Innov. Food Sci. Emerg. Technol., 11, 485 (2010); https://doi.org/10.1016/j.ifset.2010.01.013.

13. J.P. Maran, S. Manikandan, B. Priya and P. Gurumoorthi, J. Food Sci. Technol., 52, 92 (2015); https://doi.org/10.1007/s13197-013-0985-Z.

14. F. Chemat, V. Tomao and M. Virot, Handbook of Food Analysis Instruments, CRC Press Book, pp. 85-103 (2008).

15. R. Japón-Luján, J.M. Luque-Rodríguez and M.D. Luque de Castro, $J$. Chromatogr. A, 1108, 76 (2006); https://doi.org/10.1016/j.chroma.2005.12.106.

16. M. Toma, M. Vinatoru, L. Paniwnyk and T. Mason, Ultrason. Sonochem., 8, 137 (2001); https://doi.org/10.1016/S1350-4177(00)00033-X 
17. M. Vinatoru, Ultrason. Sonochem., 8, 303 (2001); https://doi.org/10.1016/S1350-4177(01)00071-2.

18. Z. Pan, W. Qu, H. Ma, G.G. Atungulu and T.H. McHugh, Ultrason. Sonochem., 18, 1249 (2011); https://doi.org/10.1016/j.ultsonch.2011.01.005.

19. P.W. Araujo and R.G. Brereton, TrAC-Trends Analyt. Chem., 15, 156 (1996); https://doi.org/10.1016/0165-9936(95)00086-0.

20. M.A. Bezerra, R.E. Santelli, E.P. Oliveira, L.S. Villar and L.A. Escaleira, Talanta, 76, 965 (2008); https://doi.org/10.1016/i.talanta.2008.05.019.

21. R. Tabaraki and A. Nateghi, Ultrason. Sonochem., 18, 1279 (2011); https://doi.org/10.1016/j.ultsonch.2011.05.004.

22. D. Bas and I.H. Boyaci, J. Food Eng., 78, 836 (2007); https://doi.org/10.1016/j.jfoodeng.2005.11.024.

23. N. Ilaiyaraja, K.R. Likhith, G.R. Sharath Babu and F. Khanum, Food Chem., 173, 348 (2015); https://doi.org/10.1016/j.foodchem.2014.10.035.

24. M. Chen, Y. Zhao and S. Yu, Food Chem., 172, 543 (2015); https://doi.org/10.1016/i.foodchem.2014.09.110.

25. H. Li, C. Tsai, A.L. Koh, L. Cai, A.W. Contryman, A.H. Fragapane, J. Zhao, H.S. Han, H.C. Manoharan, F. Abild-Pedersen, J.K. Nørskov and X. Zheng, Nat. Mater., 15, 48 (2016); https://doi.org/10.1038/nmat4465.

26. A.P. Oliveira, P. Valentão, J.A. Pereira, B.M. Silva, F. Tavares and P.B. Andrade, Food Chem. Toxicol., 47, 2841 (2009); https://doi.org/10.1016/j.fct.2009.09.004.

27. J. Wang, X. Wang, S. Jiang, P. Lin, J. Zhang, Y. Lu, Q. Wang, Z. Xiong, Y. Wu, J. Ren and H. Yang, Food Chem. Toxicol., 46, 1025 (2008); https://doi.org/10.1016/j.fct.2007.10.042.

28. K. Zhou and L. Yu, Lebensm. Wiss. Technol., 37, 717 (2004); https://doi.org/10.1016/j.lwt.2004.02.008.
29. L. Wang, Z. Wang and X. Li, J. Sep. Sci., 36, 1652 (2013); https://doi.org/10.1002/jssc.201300062.

30. P. Chuwers, J. Osterloh, T. Kelly, A. Dalessandro, P. Quinlan and C. Becker, Environ. Res., 71, 141 (1995); https://doi.org/10.1006/enrs.1995.1076.

31. S.A. Batterman, A. Franzblau, J.B. D'Arcy, N.E. Sargent, K.B. Gross and R.M. Schreck, Int. Arch. Occup. Environ. Health, 71, 325 (1998); https://doi.org/10.1007/s004200050288.

32. M. Bouchard, R.C. Brunet, P.-O. Droz and G. Carrier, Toxicol. Sci., 64, 169 (2001); https://doi.org/10.1093/toxsci/64.2.169.

33. S.R. Mousavi, M. Namaei-Ghassemi and M. Layegh, Iran. J. Basic Med. Sci., 14, 361 (2011)

34. S. Zhang, H. Bi and C. Liu, Sep. Purif. Technol., 57, 277 (2007); https://doi.org/10.1016/j.seppur.2007.04.022.

35. P.W. Tan, C.P. Tan and C.W. Ho, Int. Food Res. J., 18, 557 (2011).

36. A.E.-D.H. Sayed, N.H. Mohamed, M.A. Ismail, W.M. Abdel-Mageed and A.A. Shoreit, Ecotoxicol. Environ. Saf., 128, 189 (2016); https://doi.org/10.1016/j.ecoenv.2016.02.023.

37. H.N. Murthy, K.S. Joseph, S. Payamalle, D. Dalawai and V. Ganapumane, J. Parasit. Dis., 41, 666 (2017); https://doi.org/10.1007/s12639-016-0863-5.

38. A. Hernandez-Hernandez, F. Alarcon-Aguilar, J. Almanza-Perez, O. Nieto-Yañez, J. Olivares-Sanchez, A. Duran-Diaz, M.A. RodriguezMonroy and M.M. Canales-Martinez, J. Ethnopharmacol., 204, 1 (2017); https://doi.org/10.1016/j.jep.2017.04.003.

39. S. De Marino, F. Gala, F. Zollo, S. Vitalini, G. Fico, F. Visioli and M. Iorizzi, Molecules, 13, 1219 (2008); https://doi.org/10.3390/molecules13061219. 